\title{
Selected Reference Books of 1994-1995
}

\section{Eileen Mcllvaine}

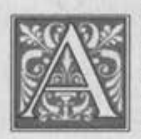

lthough it appears under a byline, this list is a project of the reference departments of $\mathrm{Co}$ lumbia University Libraries, and notes are signed with the initials of one of the following staff members: Kathe Chipman, Katherine A. Keller, Avery Library; Mary Cargill, Olha della Cava, Robert H. Scott, Sarah Spurgin, Junko Stuveras, Butler Library; Nancy Friedland, Undergraduate Library.

This article follows the pattern set by the semiannual series initiated by the late Constance M. Winchell more than fifty years ago and continued by Eugene Sheehy. Because the purpose of the list is to present a selection of recent scholarly and general works of interest to reference workers in university libraries, it does not pretend to be either well balanced or comprehensive. A brief roundup of new editions of standard works is provided at the end of the reviews. Code numbers (such as DA41 or 1CJ331) have been used to refer to titles in the Guide to Reference Books, 10th ed. (Chicago: ALA, 1986) and the Supplement ... Covering Materials from 1985-1990 (Chicago: ALA, 1992).

\section{Biography}

Maricourt, Thierry. Dictionnaire des auteurs prolétariens de langue française de la Révolution à nos jours. Amiens, France: Encrage, 1994. 253p. (ISBN 2-906389-54-4). LC 95-15122.

This biographical dictionary of French proletarian writers covers the years 1789 to the present, with the bulk of the entries from the first half of this century. Entries range from several sentences to several pages; the longer entries provide bibliographies. To be included, authors must have been from a working-class background, have written in French, and have published at least one book. Although a few of the writers (those who are very well known and whose names fall before J) have longer entries in the Dictionnaire de biographie française (AJ194), most of the writers are not easily found in other sources. More than 100 photographs of writers and their books illustrate the text. Highly recommended for libraries supporting research in French history and literature and labor studies.-S.S.

\section{Ethics}

Ethics Index: An Interdisciplinary Resource of Journal and Essay Literature in the Field of Ethics [CD-ROM]. Evanston, Ill.: American Theological Library Association, 1995- . Updated three times a year. Subscription price: $\$ 1,200$ per year (ISSN 1085-3758). LC 95-660988.

This new CD-ROM from ATLA seeks to respond to the growing interest of students and researchers in questions of ethics-from abortion to environmental preservation, from euthanasia to intellectual property rights. The index, available only in electronic format, takes a multi-

Eileen Mcllvaine is Head of Reference and Collections, Butler Library, Columbia University. 
disciplinary approach, addressing the question of ethics from the perspectives of a variety of disciplines. It likewise draws its citations from a broad range of sources - professional and academic journals, general interest periodicals, newspapers, and single- and multiauthor books. As of June, the database contained more than 31,500 records, from 1990 to date; and the editors plan to add more than 20,000 new entries each year.

The search software is the same one available on ATLA's Religion Indexes (1BB16), with the full range of logical and proximity operators and truncation and wild card searching. Searches are possible in a variety of fields, including general keyword, subject heading, author, title, journal name, publisher, language, year, ISBN, ISSN, and other standard numbers. Browsing of the index for individual fields also is possible. The CD-ROM is accompanied by a user's manual, a quick reference guide, and a list of journal titles indexed.

Although a number of the titles listed here are indexed in various other sources, this is the only database to bring this broad range of materials together into a single place. As such, it promises to be an interesting addition to the collection of any institution where research on ethical issues is a major part of the program.R.H.S.

\section{Literature}

Ashley, Mike, and William G. Contento. The Supernatural Index: A Listing of Fantasy, Supernatural, Occult, Weird, and Horror Anthologies. Bibliographies and Indexes in Science Fiction, Fantasy and Horror, no. 5. Westport, Conn.: Greenwood Pr., 1995. 933p. \$195 (ISBN 0-313024030-2). LC 95-6290.

The Supernatural Index includes more than 21,300 stories in some 2,100 anthologies published in English from 1813 (Tales of the Dead) through 1994. The bulk of the index lists works by author, providing a full citation to each anthology, as well as information about the first publication of each story. Nearly 8,000 writers are represented and the author index reads like a who's who of world literature, with entries for Shakespeare, the Brontes, George Eliot, Kafka, Dickens, Dostoevsky, and Dumas, as well as Du Maurier, Lovecraft, Conan Doyle, Mary Shelley, L. P. Hartley, Ray Bradbury, Edith Nesbit, and even P. G. Wodehouse. The Supernatural Index also provides a contents list for each anthology (with full bibliographic citation and original price), an editor index, and a short story index. It lacks a subject index for the reader who remembers only the creepy governess or that the story was set in Chicago, so it will be most useful for searching for known items, finding translations, and tracing the publishing history of anthologies of supernatural tales. Recommended for libraries of all sizes.-S.S.

\section{Black American Poets and Dramatists} before the Harlem Renaissance. Ed. Harold Bloom. New York: Chelsea House, 1995. 145p. \$24.95 (ISBN 07910-2205-6). LC 93-8344.

Black American Poets and Dramatists of the Harlem Renaissance. Ed. Harold Bloom. New York: Chelsea House, 1994. 160p. \$24.95 (ISBN 0-7910-22072). LC 94-5881.

Black American Prose Writers before the Harlem Renaissance. Ed. Harold Bloom. New York: Chelsea House, 1994. 159p. \$24.95 (ISBN 0-7910-22021). LC 93-13022.

Black American Prose Writers of the Harlem Renaissance. Ed. Harold Bloom. New York: Chelsea House, 1994. 174p. \$24.95 (ISBN 0-7910-2203X). LC 93-17979.

These four books, which share a common format, are some of the latest additions to the series Writers of English: Lives and Works. Their purpose is to introduce students to the most important information about the premier writers of the Harlem Renaissance and the period preceding it. 
There are entries for about forty-five writers in the four books; and, in some instances, an entry is repeated, almost verbatim, in one of the other books. For each writer, there is a brief biographical sketch, several lengthy quotes from leading critical studies, and a bibliography of the author's published works-useful but minimal information for those wishing to be introduced to this group of authors.

A far more thorough introduction to this group, their writings and literary criticisms can be found in either the multivolume Black Literature Criticism (Detroit: Gale, 1992. 3v. \$275) or in several volumes of the Dictionary of Literary Biography (Detroit: Gale, 1978- ; BD416, 1BD52, especially volumes 50-51, \$128 each), where all but four of the writers have biographical sketches and bibliographies that are considerably more substantive. Even with the price difference, I would recommend these two sources over the four works in question.-O.D.C.

\section{Dictionnaire des oeuvres du $\mathrm{XX}^{e}$ siècle:}

littérature française et francophone.

Ed. Henri Mitterand and Alexis Pelle-

tier. Paris: Dictionnaire Le Robert,

[1995]. 621p. 240F. (ISBN 2-85036-262-X).

This is a sequel and companion volume to Dictionnaires des grandes oeuvres de la littérature française (Paris: Robert, 1992; 706p.). Some 150 entries cover literary works, in a broad sense of the term, which were written in French and published since January 1, 1901, along with fiftyseven entries on literary magazines and seventy-three articles on movements, genres, and other special topics such as painting and literature, postmodernism, and comic books.

Similar in organization to its predecessor, each entry gives an analysis of the work, its literary context, and its relation to other works and the life of the author, followed by a bibliography of editions and critical studies. Topics, works, and journals are arranged in one alphabet. The volume ends with a chronology (lit- erature, political events, science and technology, music, cinema), and author, and title indexes.-J.S.

Schumann, Andreas. Bibliographie zur deutschen Literaturgeschichtesschreibung 1928-1945. Munich: Saur, 1994. 278p. 198DM (ISBN 3-598-11229-7).

Literary history can have nonliterary uses, as this ingenious bibliography shows. It is a list of some 600 works of German literary history written from 1827 (when August Korberstein's Grund-riss der deutschen Nationalliteratur was published) through 1945. Naturally, there were many more works published on that subject during this period, but the model introduction clearly explains the purpose of the bibliography and the reasoning behind the choices: to show the use of German literary history in order to develop a sense of German identity during the nineteenth and early twentieth centuries. Thus works intended for a narrow academic audience are excluded, but literary textbooks (excluding pure anthologies) and surveys intended for a general audience are here. The works included must cover at least a 30-year period, be written in German, and discuss German literature as a whole, not regional or local developments.

The entries are arranged alphabetically by author. An extensive series of indexes provides access by title, publisher, date, period covered, intended audience (women, schools, children, etc.), and ideology (nationalistic, anti-Semitic, etc.). The work also includes brief biographies of the authors, with citations to other biographical sources. Students in both German literature and modern German history should find this imaginative bibliography extremely useful.-M.C.

\section{Cinema}

Reclams Lexikon des deutschen Films. Ed. Thomas Kramer. Stuttgart: Reclam, 1995. 467p. 54.80DM. (ISBN 3-15010410-6). LC 95-161361. 
This Lexikon provides brief summaries and evaluations of more than 600 significant German (including Austrian and German-speaking Swiss) films from the silent era to the $1990 \mathrm{~s}$. There also is a separate section with biographical information on directors that includes citations to additional secondary sources, and a listing of additional sources on German films in general. The list of German film journal titles, divided into those published before 1945 and those after, should be a useful resource. Unfortunately, there is no index of actors, nor any way to find out which films of a specific director are listed. This is a useful resource for brief information on German films, but libraries that own more complete guides, such as Cinegraph (1BG87), will not need this one.-M.C.

\section{Art and Architecture}

America Preserved: A Checklist of Historic Buildings, Structures, and Sites. 60th Anniversary ed. Washington, D.C.: Library of Congress, Cataloging Distribution Service, 1995. 1152p. \$74 (ISBN 0-160452554). LCCN 94-19453.

An expansion of Historic America (1983) that adds some 14,000 more structures, America Preserved is the ideal companion volume to the National Register of Historic Places 1966 to 1994 (reviewed in this column most recently). The checklist covers all records held by the Historic American Buildings Survey (HABS) and the Historic American Engineering Record (HAER); HABS is the only one of the WPA programs begun in the thirties that continues today. It is our country's first effort to record systematically our built environment and has been the source of numerous published catalogs featuring individual states' records.

Listings in both America Preserved and the National Register are arranged by state and divided into counties; however, the present volume further subdivides counties by town(s) and provides an index by state, within which one can locate the ap- propriate county name for a given town. Data provided for each site are derived from the database maintained by the $\mathrm{Na}$ tional Park Service since 1982 for holdings there and at the Library of Congress, and are current through March 1994. An entry includes location, HABS or HAER inventory and shelf list number, and an indication of number of color transparencies, measured drawings, field records, photograph captions, pages of text, and photographs for a given site. Like the National Register volume, America Preserved incorporates a selection of representative images from the collection, in this case numbering over 300,000 items. The collection covers not only the states and District of Columbia, but also Puerto Rico, the Virgin Islands, Canal Zone, and Guam.-K.C.

Kjellberg, Pierre. Le Mobilier du XX' siècle: Dictionnaire des créateurs. Paris: Éditions de l'Amateur, 1994. 693p. $1100 \mathrm{~F}$ (ISBN 2-85917-177-0).

This heavily illustrated biographical dictionary of furniture designers, firms, movements, manufacturers, and design schools betrays a French bias, which was not totally unexpected in a French publication. Bias aside, however, this reference work is a worthy addition to an academic or museum library with a strong decorative arts and/or furniture collection.

Kjellberg, who has written extensively on French furniture history, begins this work with a sixteen-page essay on the history of twentieth-century furniture. The lack of bibliographical references within this essay, and within the entries themselves, is somewhat compensated for by the five-page bibliography at the end of the volume. The bibliography is divided into the following categories: General Works, Art Nouveau, Art Deco, Contemporary, Exhibitions (arranged chronologically), and Monographs and exhibition catalogues arranged by designer. The French bias is particularly evident in this last section. For example, 
for the one book each on Charles Rennie Mackintosh and Frank Lloyd Wright, there are five entries for Jacques Émile Ruhlmann. A helpful addition to this section is a chronological listing of the major French design magazines, with their date(s) of publication, and a listing of eight major foreign magazines devoted to this area. Another very useful feature is a listing of museums that have strong collections of twentieth-century furniture. The coverage of the Paris museums is particularly detailed. Other French museums and foreign museums with their collection strengths (by period and designer) also are included.

This work is confined primarily to major twentieth-century furniture designers and is international in scope. All styles and periods are represented, from Art Nouveau to Bolidismo, from Eileen Gray and Henry Van de Velde to Andree Putman and Philippe Starck. Entries, in essay format, contain standard biographical information and are written in a qualitative style. Some entries are rather short, such as that for the architect Norman Foster, which includes one color photograph. The emphasis is on his furniture design. The entry for Émile Gallé, conversely, spans ten pages and has eighteen photographs, in color and black and white. Although well illustrated, very few works are shown in situation-a definite weakness. But when compared to the much shorter Gallé entry in Mel Byars's Design Encyclopedia (London: Wiley, 1994; 612p.), Kjellberg's extensive knowledge and enthusiasm come through.

For information on twentieth-century women designers, consult Frauen im Design: Berufsbilder und Lebenswege seit 1900 (Stuttgart: Design Center Stuttgart, 1989; 2 vols.), in German and English, an exhibition catalog devoted to twentieth-century European women designers, primarily German. Included is an illustrated biographical section on twenty-nine "international pioneers" with exhibition, award, and bibliographical information.
Le Mobilier $d u X^{e}$ siècle fills an important gap as a well-illustrated biographical dictionary with evaluative essays, with its strength in French designers. Perhaps an English edition will be forthcoming.-K.K.

\section{Ethnic Studies}

Black American Colleges \& Universities: Profiles of Two-Year, Four-Year \& Professional Schools. Detroit: Gale Research, 1994. 796p. \$60 (ISBN 0-81039166-X). LC 94-3898.

There are several reasons why this guide is an invaluable resource to the student interested in attending a historically Black college or one that, though not historically Black, has a predominantly Black enrollment.

The preselection, both famous and lesser-known schools are included, makes combing through voluminous general guides to American colleges and universities unnecessary. Moreover, its focus on only 118 institutions-91 four-year, 22 two-year, and five professional schoolsmeans more comprehensive entries than are usually found in more general guides. Along with such standard information as address, phone numbers, cost, admissions and graduation requirements, etc., there is information on the school's history, the faculty and student body, the majors and preprofessional programs offered, the grading system, the athletic programs, the library holdings, and student life in general. Particular attention is given to financial aid information and information on special programs such as continuing education, honors, internships, study abroad, and off-campus study programs. Much of the information, the compilers assure us, is supplied directly by the institutions.

The book's straightforward arrangement (by state and then alphabetically by name within each state), clear layout, intelligible presentation, and variety of indexes make it very easy to consult. Preceding the body of the work are several 
brief, but useful essays, including an overview of the evolution of historically Black colleges and universities, hints on finding the most suitable school, and help on how to look for funds. Any library that serves Black students should have this work.-O.D.C.

Brown, Lorene Byron. Subject Headings for African American Materials. Englewood, Colo.: Libraries Unlimited, 1995. 118p. \$31 (ISBN 1-563-08252-7). LC 95-10847.

This handy guide gives librarians and information professionals a useful list with which to classify and retrieve African American-related materials. It also can serve to introduce students and faculty to the complexity of organizing information about the African American experience. Subject control of any interdisciplinary area is problematic, but when one adds to it the variability and fluctuation of language that has been used to speak about African Americans, one can appreciate the service this work renders.

What the compiler has done is to extract from the multivolume sixteenth edition of the Library of Congress Subject Headings (LCSH) all those headings that not only pertain directly to African Americans, such as "Creole dialects, English," but also the many others, such as "Consumer credit," for example, that apply to all and yet are in some way relevant to African Americans. The result is an alphabetically arranged list of 5,000 topical, corporate name, and some personal name headings that can guide the librarian in the organization and retrieval of information related to African Americans. The headings are listed in the familiar-at least to librarians-format of the LCSH, including scope notes, cross-references, and listings of broader, narrower, and related terms. Adetailed introduction to the arrangement of the guide helps orient the uninitiated to the mechanics of the LCSH format. Bowing to current usage, the compiler has made two important alterations in terminology: the official LCSH "AfroAmericans" has been changed to "African Americans" and the heading "African American Universities and Colleges" has become "Historically Black Colleges and Universities."

A significant contribution is the presentation of examples of complicated entries with many subheadings to act as models for similar entries; thus the entry "National Association for the Advancement of Colored People" and its 184 subheadings serve as the model for all corporate bodies, "Martin Luther King, Jr." for individuals, "Toni Morrison" for individual literary authors, "Lincoln University" for educational institutions, and so on. This work is a useful addition to any institution that collects information on African Americans.-O.D.C.

\section{Historical Statistics of Black America.}

Comp. and ed. Jessie Carney Smith and Carrell Peterson Horton. Detroit: Gale Research, 1994. 2 vols. 1xxxii, 2244p. \$125 (ISBN 0-8103-8542-2). LC 94-29718.

In 1990 Carrell Peterson Horton and Jessie Carney Smith published the second edition of Statistical Record of Black America (1CC211), a voluminous register of African American statistical information. Now they have enriched the field with a two-volume companion work, Historical Statistics of Black America. Whereas the former concentrated on statistical information covering the past twenty years, the latter takes many of the same subject areas - education, labor, population characteristics-and extends the coverage back to the early seventeenth century.

Historical Statistics of Black America is a monumental compendium chronicling the "conditions, status, and experiences of African Americans" (Introd.) from 1619 to 1975 , telling us, for example, the location of Black farms in 1930 by type of farm and by geographic region, or the colleges and universities with Black inductees into Phi Beta Kappa during the period 1874- 
1916. In total, there are 2,320 tables covering nineteen topics, including large sections dealing with Agriculture, Education, Labor, Population and Vital Statistics, as well as smaller sections devoted to Business, Crime, Family, Housing, Income, Media, the Military, Politics, Religion, Slavery, and Sports, all further divided by subtopic. Access to the data is through either the topically arranged table of contents, which lists the full title of each statistical table, or a back-of-thebook subject index. Because the chronological evolution of the African American experience is partly lost as a result of the topical presentation, an index by year is also provided.

Most of the material assembled here has come from U.S. government publications, but much was also drawn from publications originating at African American institutions or coming from African American authors, such as, for example, The Negro Year Book (1947, 1952; CC425) or The Negro Handbook (1942-1949; CC421). The work contains no narrative text at all, except in some rare instances when a statistical narrative is cited in lieu of a table. The tables are extremely well documented. Each has a footnote designating the source, or sources, of the information and noting any facts that need to be considered in interpreting the numerical data. A bibliography of these sources is included. Moreover, the tables are visually crisp, clear and uncluttered, and use a large enough typeface to make them legible. Comprehensive, thorough, and easy to use, this work is highly recommended for any library.-O.D.C.

\section{Tong, Diane. Gypsies: A Multidisciplinary} Annotated Bibliography. Garland Reference Library of Social Science, 579. New York: Garland, 1995. 399p. \$60 (ISBN 0-8240-7541-2). LC 94-36437.

The disciplines referred to in the subtitle are used as chapter headings, which range from anthropology to women. Within each chapter, entries are arranged alphabetically by author. Unfortunately, there are no geographical or chronological subdivisions, which is a drawback for a wide-ranging topic such as Gypsies. Browsing can seem a little breathless. In the anthropology chapter, for instance, an article on "Gypsies in California" is followed by "The Manufacture of Pots and Pans among the Gypsies of Kosovo and Metohija."

There is a detailed subject index, which, though helpful, must be used with care. There are entries, for instance, under "Britain," as well as under "England," "Wales," and "Scotland," with no crossreferences. "Travellers," a slang term for Gypsies in the British Isles, appears, as does "Gypsy groups." "Germany" is a heading, as well as "Nazi Germany." I could find no entry in the subject index that would lead to works on the origin of the Gypsies though I did find a few works that discussed this topic in the history chapter.

The author lists popular and scholarly works (books, articles, and dissertations) written from about 1960 through 1992, though many earlier works are provided, particularly in the bibliography chapter (a very useful selection). The fiction (adult) chapter also includes many pre1960 works, though perhaps the most famous novel about the Gypsies, George Borrow's Lavengro, is not listed, whereas Jane Eyre and Emma are listed.

The works included are almost all in English. It is surprising to find a work intended for the academic audience stating, "Some of the most progressive recent work is published in Germany, and since I don't know German well, I've included some unannotated references to works that look intriguing" (Introd.).

The author has compiled some useful material, and the annotations are thorough, though somewhat ideological. She dismisses much of what is written as a "poisonous brew of racism and sexism" (p. 95). This work will be a useful addition to ethnic studies collections, but se- 
rious researchers will need to use additional sources.-M.C.

\section{Marxism}

\section{Historisch-kritisches Wörterbuch des}

Marxismus. Ed. Wolfgang Fritz Haug. Hamburg: Argument, 1994-, vol. 1, pt. A. 109DM per volume. (ISBN 3-88619431-0). LC 95-162952. (In progress.)

This monumental (vol. 1, pt. A, reaches avant-garde), long-term project (estimated completion date is 2000) is an encyclopedia of Marxism in its broadest sense. It defines and discusses terms - no individuals are included-used by Marx and comments on their application by later doctrinaire and not-so-doctrinaire followers. As an historical encyclopedia, it also includes concepts, such as antifascism, that later Marxists wrote about.

There is a wide variety of subjects. The first volume has entries ranging from Arabic socialism, reduction of working hours, atheism, and aesthetics. Each entry, signed by one of the more than 500 contributors, summarizes the main ideas of Marx and other important Marxist thinkers, and provides a bibliography of major primary and secondary sources, including works in English. All large social science and history collections will need this work.-M.C.

\section{World War II}

\section{Blanc, Brigitte, Henry Russo, and Chan-}

tal de Tourtier-Bonazzi. La Seconde guerre mondiale: guide des sources conservées en France 1939-1945. Paris: Archives nationales, 1994. 1217p. 350F. (ISBN 2-86000-235-9). LC 95-138497.

A collaborative work of archivists of the Archives Nationales and historians at the Institut d'Histoire du Temps Présent, the guide inventories available French historical sources on World War II regardless of format and place of conservation. Included are materials on paper and in audiovisual media, images, and sounds, as well as texts drawn from all types of organizations: public, private, archives, libraries, and museums in France and French overseas territories.

Roughly one-third of the entries are devoted to the Archives Nationales in Paris and Fontainebleau (Centre des Archives Contemporaines) and the Centre des Archives d'Outre-mer in Aix-enProvence. The sources in the Archives Nationales have diverse origins: most typically, they come from ministries and public administrations along with donated, purchased, or consigned private archives. Some were part of the archival records collected by archivists for the Haute Cour de Justice, established in November 1944 for trials of officials of the État Française and then removed from the trial documents to be transferred to the Archives. The archives of the late Third Republic, which were abandoned in Tours, were incorporated into the Archives Nationales only in 1989 . Telegrams from 1940-44 were discovered in the central post office of Vichy as recently as 1994.

The material is divided into four parts: (1) holdings of the Archives Nationales; (2) Ministries, Parliament and Conseil d'État; (3) local administration, departmental, and municipal archives; and (4) other institutions such as libraries, banks, chambers of commerce, research centers, museums, and associations.

The holdings of the Archives Nationales are listed in order of their classification scheme. Description is detailed enough to allow researchers to make a preliminary selection of records they want to consult in person. Available research tools, from typed inventories to published works, are listed whenever applicable. Departmental and municipal archival resources are listed under topics such as general administration, agriculture, social services, economy and industries, purges, civil defense, war damages, labor, prisoners of war, reconstruction, refugees, rationing, and so on.

The index by names and topics allows researchers to find these subjects across geographic and administrative bound- 
aries. The index is hard to use, however, because many entries are too broad. Look up, for example, "communes" and you find almost one whole column of page numbers with very few subtopics. ACDROM version of this guide with a good search engine would have increased its usefulness. The guide has three maps: France under occupation and German military command posts in France in March 1941 and August 1944.--J.S.

\section{The Oxford Companion to the Second}

World War. Gen. ed. I. C. B. Dear, cons. ed. M. R. D. Foot. Oxford: Oxford Univ. Pr., 1995. xxii, 1343p. maps. £36. (ISBN 0-19-214168-6). U.S. title: Oxford Companion to World War II. New York: Oxford Univ. Pr., 1995. 1343p. \$60 (ISBN 0-19-866225-4). LC 95-148182.

Fifty years after the end of World War II, scholars primarily from England but also from the United States, Australia, and former enemy countries collaborated on this reference book. The work covers World War II as defined in current AngloAmerican usage, namely the time period from September 1, 1939, to September 2, 1945. Its primary object is to explore the factors that shaped the world of today. Topics, which range from what could be roughly defined as military history to social history, were selected because of their "interest and relevance for current study." "African Americans at War" has a handy table of enlisted African Americans by category (p. 7).

All articles are signed and many include a short bibliography. They vary in length from a few lines to several pages, for example, eight pages on religion and six pages on lend-lease. Typical articles discuss countries, military leaders, battles, organizations, ships and aircraft, events and general topics (prisoners-ofwar, medicine, for example). Even a more specific topic, such as frogmen, not only gives the definition and describes its Italian origin, but also surveys the use of similar underwater teams by the United
States and Japan, thus giving a wider scope to the topic.

Articles on countries that were major participants in the war give some structure to this dictionary. A typical article on a country is about thirty pages and is subdivided into six to ten sections: introduction; domestic life; war effort; economy; government; defence forces and civil defence; intelligence; merchant marine; and culture. For some countries, appropriate special topics are added-for example, Northern Ireland and Empire for the United Kingdom.

The work gives a comprehensive, onevolume coverage of the history of the world during the war. Topics encompass the varied aspects of life in the midst of the war, from wartime civil defence in London to Nazi concentration camps and a range of tools of war from quaint carrier pigeons to atomic bombs. The generally moderate, scholarly tone of the work makes it suitable to all levels of readership from high-school students to professional historians. Numerous maps, charts, photographs, a chronology, and a table of place-name changes enhance the volume.-J.S.

Pimlott, John. The Viking Atlas of World War II. London and New York: Viking, 1995. 224p. 29cm. (ISBN 0-670-853-749). U.S. title: Historical Atlas of World War II. New York: Henry Holt, 1995. \$45 (ISBN 0-8050-3929-5). LC 94-39820. The Viking Atlas of World War II, a mix of narrative texts and maps, somberly starts with the table of the estimated loss of life in the war. A chronology covers from the end of World War I to November 1945. The book divides the time period into five stages: the interwar period, the Axis ascendant, turning the tide, Allied offensive, and Allies victorious. The maps and text follow a chronological order, covering both European and Pacific fronts.

Although this atlas makes some effort to bring out salient features of the war using quotations from those directly in- 
volved in the war, the work is not a thoroughly thought-out and executed job. Corregidor on the map (p. 207) is wrongly located at the tip of the Bataan peninsula, although the location is correctly identified as an island off the peninsula elsewhere (p. 91). Some full-page reproductions of paintings are neither informative nor artistically interesting. Maps tend to be overcharged and do not use colors effectively. The Oxford Companion to the Second World War (above) does a better job of conveying information with black-andwhite maps. If one needs to make a choice among innumerable reference works on World War II, which lately crowd bookstore shelves, this is probably not the first pick.-J.S.

\section{History and Area Studies}

Encyclopedia of New York City. Ed. Kenneth T. Jackson. New Haven, Conn.: Yale Univ. Pr., 1995. 1350p. \$60 (ISBN 0-300-05536-6). LC 95-2811.

New York City enjoys a reputation for age, size, extreme density, noise, entertainment, etc., which Professor Jackson and his coauthors have done much to address. Some 4,300 articles by sixty-eight authors provide basic, usually brief information on groups, neighborhoods, people; events, and topics. A few subjects, such as literature, dance, filmmaking, government, and politics, are given quite lengthy coverage. Many articles give at least one bibliographic citation to lead on to further research. The articles are well illustrated with clear photographs, but it is the additional tables and charts that show amazing work-for example, tables of ferry routes, major fires, organization of the railroad, a list of songs and compositions inspired by New York City, tables of eighteenth-century newspapers by date of the first issue, and a list of ticker-tape parades. The volume ends with an index of names of people who are not the subject of individual entries.

One has such fun browsing, stopping to read articles such as community gar- dens, the Bronx, Diamond Jim Brady. Because New York is such a microcosm, there is much here for everyone.

And, of course, one can nitpick-for example, why an article on Dannon but not Haagen Dazs, Planned Parenthood but not Concern For Dying, why not a list of novels with a specific neighborhood as their setting, why a description of orphan trains but no identification of them as such, why Lou Gehrig but not Joe DiMaggio (it can't be that only people not living were included because David Dinkins and Rudolf Giuliani are there)? Even with cross-references, it is still the lack of a good subject index that is the chief drawback. For example, there are articles on homelessness and poverty but not on welfare or foster care, and there is no index to bring all the articles together on the public welfare system.

Still, this is a remarkable work showing much care in compiling it with a clearly defined purpose and great accuracy. It will be heavily used by anyone from junior high schools, public libraries, or research libraries who is interested in New York City.-E.M.

Frame, Murray. The Russian Revolution, 19051921: A Bibliographic Guide to Works in English. Bibliographies and Indexes in World History, no. 40. Westport, Conn.: Greenwood Pr., 1995. 308p. \$79.50 (ISBN 0-31329559-X). LC 95-2463.

This volume offers very thorough coverage of a historic event that is certain to long excite the interest of historians, the Russian Revolution; and given the seeming end to the era to which that revolution gave birth, the timing of its appearance seems appropriate. Contained within this volume are approximately 4,000 citations to books, articles, and dissertations in English relating to the history of Russia from 1905 to 1921 . As the author notes, the only area in which a conscious effort to limit listings was in the field of literature, and the depth and range of coverage is indeed impressive. 
It is hard to think of a relevant author or work that has not been included in this compilation. To be sure, no work is ever completely comprehensive. A search of the RLIN and Historical Abstracts (DA20) databases does yield a few more titles of relevant works in English, and the initial listing of reference works and bibliographies seems unduly narrow, but these do nothing to diminish the valuable service the author has performed in bringing together so much of the English language literature on the topic in one place.

The entries are not annotated, but a detailed and logical arrangement of the contents by topic facilitates the location of the appropriate information, as do a personal name index and a subject index (the latter simply an alphabetic arrangement of the many topical headings into which the work is divided).

In short, this is a work that most libraries with serious coverage of Russian or even simply general world history will want to acquire, for it places in the researcher's hands an ample survey of the work done to date on a key historical event.-R.H.S.

\section{Oxford Encyclopedia of the Modern Islamic \\ World. Ed. John L. Esposito. New York.: \\ Oxford Univ. Pr, 1995. 4 vols. \$395 (ISBN \\ 0-19-506613-8). LC 94-30758.}

A timely effort, this reference work "provides immediate access to current scholarship on the presence and influence of Islam on a global scale" (p. $i x$ ). With 750 articles contributed by more than 450 authors, the encyclopedia represents a wide range of disciplinary perspectives illustrating the Muslim experience through political, social, and historical events and theories.

Authoritative reference works such as the Encyclopaedia of Islam (BB524, 1BB125) and the Cambridge History of Islam (Cambridge: Cambridge Univ. Pr., 1970; 2 vols.) have relied on classical texts providing extended discussions of classical and medieval history. It is the effort of The Ox- ford Encyclopedia of the Modern Islamic World to supplement and distinguish itself from these previously mentioned works in three ways: (1) by focusing on the modern world, rough-ly beginning with the end of the eighteenth century to the present; (2) representing methodologies of the social sciences and humanities; and (3) drawing on comparative studies. For example, there are entries for the Nation of Islam, Palestine Liberation Organization, and, in a recurring, comparative format, the entry on Muslim Brotherhood is composed of separate articles that present an overview and discussion of the organization in four representative countries.

The arrangement of the encyclopedia is alphabetical with articles that range from major essays on larger theoretical topics to briefer entries for descriptive topics, including succinct and comprehensive entries for people, places, events, organizations, movements, theories, religion, law, politics, literature, and art. Each entry is enhanced by cross-references and bibliographies for related and further readings. The longer essays include a table of contents at the beginning that outlines the coverage of the topic. Useful bibliographic essays appear under the headings for "Periodical Literature" and "Reference Books." The work is geared toward the scholar, student, or general reader, and provides a very good index, a synoptic outline of contents to highlight the conceptual scheme of the encyclopedia, and a directory of the many contributors.-N.F.

\section{Who's Who in Russia and the CIS Repub-}

lics. Ed. Vladimir Morozov. New York: Henry Holt, 1995. 328p. \$60. (ISBN 08050-2691-6). LC 94-32820.

The sweeping changes of the past seven or eight years in the former Soviet Union have brought to the fore a new and changing array of actors, depriving specialists as well as interested laypersons alike of the relatively easier orientation to person- 
nel than was possible under the traditionally more stagnant Soviet regime. Hence, the appearance of a guide to the new cast of characters is a welcome event.

The latest such offering, Who's Who in Russia and the CIS Republics, offers a listing of approximately 1,100 prominent figures in government, business, public organizations, cultural institutions, and sports and entertainment in Russia and the other republics of the Commonwealth of Independent States (CIS), with a decided emphasis on Russia. Edited by Vladimir Morozov, the book is published under the auspices of VIP, a Russian magazine on "politics, public affairs, and business." The biographical information has been provided by the listed individuals themselves. A typical entry contains information on the individual's current position, date and place of birth, nationality, education, career, major publications, family, and home and office addresses. Listings by profession and by organizational or governmental affiliation provide an additional means of searching out entries, and a list of the recipients of honors and awards (but not the awards they received!) and a list of published works cited in the various entries also are provided.

Comparisons are most likely to be drawn to Who's Who in Russia and the New States, eds. Leonard Geron and Alex Pravda, and published by I.B. Tauris in 1993. The focus of the two works is slightly different, as the newer volume makes no effort to cover the Baltic states, which are not part of the CIS, but the divergences are, in fact, much greater than this minor difference might suggest. The earlier volume contains many more entries, approximately two to three times as many. Conversely, the amount of data contained in each entry, which appears not to have been provided by the individuals themselves, is considerably briefer. Moreover, the 1993 work is much more heavily focused on the political, although some other areas are represented as well. For all of these reasons and also, no doubt, because of the rapid changes still taking place in Russia and the CIS, there is a fairly small degree of overlap in coverage between the two volumes. Comparing the listings for the letters $\mathrm{Z}$ and BA-BE, for example, one finds eighty-eight entries in the Morozov volume and 235 in the Geron and Pravda volume, with only thirty-one individuals appearing in both works.

In short, it would appear that both volumes are needed for a library to provide broad English language orientation to the evolving Russian scene. It is, as the introduction notes, "designed to be a handy desk reference for researchers, journalists, business people, diplomats, and students."-R.H.S.

\section{New Editions and Supplements}

Bryan and Valerie Falk continue to compile the Personal Name Index to the "New York Times Index," 1975-1993 Supplement (Sparks, Nev.: Roxbury Data Interface, 1995. vols. 1-3, A-Kor. To be in 6 volumes; $\$ 86.75$ per volume). The original Personal Name Index to the Index for which this is a supplement covers 1851-1974 (AF79, 1AF12). This new compilation supersedes earlier indexes for 1975-1979, 1975-1984, and 1975-1989.

The annual printed version of Index Translationum (AA169) ceased in 1992 and has been replaced by a CD-ROM version (Paris: Unesco, 1994- , \$1,200). The CDROM will be updated annually and will cumulate from 1979; the 1994 disc includes translation published from 1979 through 1992, with a few works appearing in 1993. A user guide is included on the disc, which is easy to print out, and there are content-sensitive help screens. The file can be searched by author, title (though the original title is not consistently provided), country of publication, language (both original and language of the translation), translator, publisher, broad subject, or any combination of these.-M.C. 
Several indexes to multivolume sets have been published this year. Dictionnaire de spiritualité: tables générales (Paris: Beauchesne, 1995; 732 col., BB239) provides a topical index (including personal names) to the set. Also included is the Liste of collaborateurs, naming the individual authors and their contributions (41 unnumbered pages). The Bibliographie der deutschsprachigen Arabistik und Islamkunde (Frankfurt: Institut für Geschichte der Arabisch-Islamischen Wissenschaft;1DE8) offers with volume twenty $(1995 ; 383 p$.) the Personenregister and the Register der Primärliteratur (by title) with reference to volume and page. Poggendorff's Biographisch-literarisches Handwörterbuch zur Geschichte der exakten Naturwissenschaft (Berlin: Adakemie-Verlag; EA232) is the standard biographical resource for the natural sciences. Volume VIIb covers scientists not German or Austrian or Swiss who flourished during the period 19321962. Now the compilers have issued a Bibliographie der Periodika $(1994 ; 368 \mathrm{p}$.) for those abbreviations of journals used in this part. Reference for each is given to a list of union lists, library catalogs, and descriptive notes.

Donald J. Winslow updated and expanded his dictionary Life-Writing: A Glossary of Terms in Biography, Autobiography, and Related Forms (Honolulu: Publ. for the Biographical Research Center by Univ. Hawaii Pr., 1995. 76p. \$5; 1st ed. 1980 ) to include over 100 new terms (for example, biodigm, autogynography), to add to entries (for example, postmodernism), and generally to revise the dictionary. "I try to confine myself to terms concerned with literary genres and with the general human condition" (Pref.).

Jacob Blanck's Bibliography of American Literature (BD364, 1BD151) covers some 280 American authors from the late eighteenth to the early twentieth century in nine volumes. Professor Michael Winship, who completed volumes 7 through 9 , now offers indexes to the set: Bibliogra- phy of American Literature: A Selective Index, with Philip B. Eppard and Rachel J. Howarth (Golden, Colo.: North American Pr., 1995; 345p. \$70) for titles (primary titles, variant titles, binders titles, series titles), dates (chronological by the year on the title page or copyright notice), and United States and foreign publishers (alphabetical by city, then publisher, then year).

Further riches include Winship's Epitome of Bibliography of American Literature (Golden, Colo.: North American Pr., 1995; 325p. \$55), also with Eppard and Howarth. This is a condensed or abridged form of the Bibliography including "those items given full entries" and then "only primary works in separately published books." An asterisk indicates that "significant additional information will be found in the full BAL entry" (Introd.).

Just published is the second edition of A Bibliographical Guide to the Study of Western American Literature, compiled by Richard W. Etulain and N. Jill Howard (Albuquerque: Univ. of New Mexico Pr., 1995; 471p. \$39.95; 1st ed., 1982. BD365). The volume lists secondary literature on about 400 major authors who wrote mainly about the western part of the United States, including such writers as William Sydney Porter (a.k.a O'Henry), D. H. Lawrence, Owen Wister, and The Beats. This new edition includes almost everything and everyone from the first edition except for master's essays, introductions, a few older volumes, and brief essays which were dropped. Added to the topical section are listings of materials on women and western literature and the environment and western literature, as well as about thirty-five new authors (for example, Louise Erdrich and Ursula LeGuin). Author index only.

Anatomy of Wonder 4: A Critical Guide to Science Fiction, compiled by Neil Barron (New Providence, N.J.: Bowker, 1995; 912p. \$52. BD264, 1BD109) extends its coverage of science fiction literature, both the texts themselves and the secondary 
literature and research aids, to 1993 with a few last-minute additions in November 1994. Added also is a theme index (robots, fantastic voyages) and a series index; omitted, though, are citations to any science fiction tale that has not been translated into English. If your library is very interested in this topic, you will want to retain the third edition, which has 206 pages of titles in foreign languages. Barron states that he expects this to be the last edition he will compile.

It is indicative of a recent publishing trend that the four titles cited here for art and architecture are biographical dictionaries. The third edition of Colvin's A Biographical Dictionary of British Architects 1600-1840 has just appeared, this time from the Paul Mellon Centre for Studies in British Art (New Haven, Conn.: Yale Univ. Pr., 1995; 1264p. \$65). First published in 1954 under a slightly different title, with a second edition in 1978 (BE294), the new edition adds over 160 biographies and 2,000 buildings. Appendixes continue to be extremely useful and include a listing of names from the 1954 and 1978 editions excluded from the 1995 edition.-K.C.

Also available in its third edition is Contemporary Architects (New York: St. James Pr., 1994; 1125p. \$149), edited by Muriel Emanuel, and published previously in 1980 and 1987 (BE295, 1Be132). The 1994 edition adds seventy new entries and revises 330 of the 585 existing ones, deletes most entrants who died before 1960 , and broadens the definition of architect for inclusion.-K.C.

Bernard Oudin's Dictionnaire des architectes (Paris: Seghers, 1994; 663p. 198 F) was first published in 1970 . The revision and enlargement also incorporate a few topics along with proper names, and retain and expand the small glossary and excellent building index, arranged by country and city.-K.C.

The definitive source for Danish artists' and architects' biographies has been published in an expanded and wonder- fully thorough multivolume set, Dansk Kunstnerleksikon (Kobenhavn, Denmark: Munksgaard, 1994-, vols. 1-3, A-Iverson. In progress). The first edition by Philip Weilbach had the title Dansk Konstnerlexikon (1877-78), the second edition had the title Nyt dansk Kunstnerlexikon (18961897), and a third edition was entitled Weilbachs kunstnerlexikon (1947-1952). Entries cite all pertinent personal data, including awards, exhibitions, bibliography (sometimes extensive), and critical comments, for individuals born through the late 1950s.-K.C.

The Atlas des diasporas, compiled by Gerard Chaliand and Jean-Pierre Rageau (Paris: Ed. Odile Jacob, 1991) offered text, maps, population tables, chronologies for the movements of the Jewish, Armenian, Gypsy, Black, Chinese, Indian, Irish, Greek, Lebanese, Palestinian, Vietnamese, and Korean diasporas. That Atlas has now been translated by A. M. Berrett, Penguin Atlas of Diasporas (London: Viking, 1995. 183 p. \$34.95) with the same text, maps, etc., and even the same size, $19 \times 25 \mathrm{~cm}$.

Bibliographies of New England offers a volume for each of the New England states and a volume for the region (DB121, 1DB49). With volume 9, Further Additions to 1994 (Hanover, N.H.: Univ. Pr. of New England, 1995; 299p. \$40), the compiler, Roger Parks, adds some additional 4,231 entries for books, dissertations, pamphlets, and journal articles mainly published since 1989 , though earlier omissions are included. The arrangement is geographical with at least one library location; it is indexed by authors/editors/ compilers and subjects and place names. The compiler indicates he is planning to continue bibliographical coverage of the region.

Chris Cook and the British Library of Political and Economic Sciences provided researchers with an archival guide for 1900-1951, Sources in British Political History (DC287). Now Cook and David Waller have extended that coverage for the period since 1945: St. Martin's Guide 
to Sources in Contemporary British History [(New York: St. Martin's Pr., 1994; 2 vols.; Vol. 1: Organisations and societies (372p.; \$69.95); Vol. 2, Individuals (383p.); British title: Longman Guide to Sources in Contemporary British History (Harlow, Essex: Longman, 1994. 2 vols.)], based on a survey conducted by the British Library of Political and Economic Sciences. Volume 1 of the new guide concentrates on locating papers of "political parties, trade unions and other organisations directly involved in politics and political controversy ... though many of the societies mentioned .... are not primarily or even partly political organisations, yet their archives can be of value to the historian in putting political facts into context and tracing the interaction between politics and the people" (Introd.). There also is an appendix for organisations of Northern Ireland. The second volume describes the careers and the archives, with notes on the location and availability of the records, for "more than 1000 individuals involved in British politics and public life after 1945" (Introd.).

Cook also has compiled The Making of Modern Africa: A Guide to Archives (New York: Facts on File, 1995; 218p. \$35), which offers similar coverage of more than 1,000 private papers covering the period 1878 to the end of colonial rule. Arrangement is alphabetical with a brief description of the person's career followed by notes on the location and contents of the archive. Two indexes complete the volume: lists of archives and of subjects. One is happy to note that Professor Cook sees future editions that will include the "ever-growing corpus of personal archives from black Africa itself" (Pref.).

The Cambridge History of Latin America, vol XI: Bibliographical essays, edited by Leslie Bethell (Cambridge: Cambridge Univ. Pr., 1995; 1043p. \$89.95) brings together all the bibliographical essays from the earlier volumes. These have been updated and expanded to include publications at least to 1990 with some to 1992 , together with a few previously unpublished essays. The 141 bibliographic essays by 119 authors concentrate mainly on secondary literature in books, chapters in books, articles, and Ph.D. dissertations in English, Spanish, and Portuguese, with a few citations for French and German materials. The volume concludes with an author index to all the items cited.

The second edition of Roderic Ai Camp's Mexican Political Biographies was published in 1981. Now about fifteen years later, the third edition has been published (Austin: Univ. of Texas Pr., 1995; 985p. \$55) to provide "biographies of public figures, living or deceased, who have been prominent in Mexican political life from 1935 to mid 1993" (Note). In this edition "of the original 1,350 biographies, more than half have undergone significant additions or changes" and there are 600 new ones, all with updated bibliographical references. The appendix lists the most important elected or appointed political positions, for example, senators and deputies, Supreme Court justices, and so on. In this edition, these lists have been extended to include the names of oficiales mayores, union leaders, and several new ambassadorial positions. Interesting, too, is the "Selective Bibliographical Essay" which evaluates the sources of information used in compiling the dictionary.

Useful also to those studying Mexico is volume 8 of the Diccionario histórico $y$

\section{Index to advertisers}

Archival Products
BIOSIS
Blackwell
EBSCO
Greenwood
Library Technologies
Minolta
Rainbow Media
Readmore
Todd Enterprises

131 cover 3 106 105 cover 2 109 152-53 121 122 cover 4 
biographico de la Revolución Mexicana: sección internacional for foreign organizations, people, and events that have had an impact on the Mexican Revolution (Mexico: Instituto Nacional de Estudios Históricos de la Revolución Mexicana, 1994; 458p.). These include such examples as the Agency of Private Detectives, Mary Harris Jones (a.k.a Mother Jones), Mutual Film Corporation, and Zimmermann Telegram. The articles vary from a paragraph to several pages. At the end of each is a reference to a specific item in the bibliography of sources.

The Modern Encyclopedia of Russian, Soviet and Eurasian History, edited by
George N. Ryne (formerly Modern Encyclopedia of Russian and Soviet History; retitled with vol. 56) is beginning a Supplement (Gulf Breeze, Fla.: Academic International Pr., 1995; vol. 1, A-Type RocketsAlma-Ata Agreements; in progress) and intends to update and expand the earlier encyclopedia. The Supplement was considered crucial because of the "powerful changes in Soviet institutions... wrought by the collapse of the Soviet Union in 1991" (Pref.). Much fuller treatment is provided for the history of non-Russian areas and cultures. Each signed article closes with a current bibliography, which can vary from a few references to a page.

\section{IN FORTHCOMING ISSUES OF COLLEGE \& RESEARCH LIBRARIES}

Analysis of Trends in Demand for Computer-Related Skills for Academic Librarians from 1974 to 1994 - Yuan Zhou

Do Instruction Skills Impress Employers?-Chris Avery and Kevin Ketchner Use of Series Title Authority Cross-References at a Large University Library-Henry H. McCurley Jr. and Elizabeth J. Weisbrod 